\title{
PENGARUH BAHAN AJAR TEMATIK TERPADU TERHADAP PENINGKATAN PARTISIPASI PESERTA DIDIK MELESTARIKAN LINGKUNGAN DI SEKOLAH DASAR
}

\author{
Tri Juna Irawana ${ }^{1}$, Firman $^{2}$, Neviyarni ${ }^{3}$ \\ Universitas Negeri Padang, Sumatera Barat, Indonesia ${ }^{1,2,3}$ \\ Email : trijunairawana50@gmail.com ${ }^{1}$, firman@konselor.org ${ }^{3}$, neviyarni@ konselor.org ${ }^{3}$
}

\begin{abstract}
Abstrak
Penelitian ini dilaksanakan di Sekolah Dasar Kecamatan Pasaman. Penelitian ini dilatar belakangi karena guru kurang mampu melibatkan siswa berpartisipasi untuk ikut serta melestarikan lingkungan. Berdasarkan analisis yang peneliti lakukan hal ini disebabkan pada materi yang ada pada buku siswa masih sedikit, sehingga pengetahuan yang didapatkan siswa masih sedikit, dan Tampilan yang ada pada buku siswa kurang menarik perhatian peserta didik dalam belajar. Usaha untuk membuat siswa berpartisipasi dalam melestarikan lingkungan dapat dikaitkan pada pembelajaran terpadu. Sementara materi pada buku guru dan buku siswa yang disediakan di Sekolah Dasar Kecamatan Pasaman sudah berkaitan dengan tema-tema untuk memudahkan guru dan siswa untuk melaksanakan proses belajar mengajar. Tetapi, buku guru dan buku siswa tersebut masih dangkal materinya sehingga perlu diinovasi khususnya buku siswa. Untuk melengkapi buku siswa tersebut disusunlah bahan ajar tematik terpadu yang berguna untuk meningkatkan tujuan pembelajaran. Salah satu tujuan pembelajaran adalah siswa dapat menerapkan apa yang dipelajari dalam kehidupan sehari-hari. Misalnya, siswa sudah tahu cara-cara melestarikan lingkungan, setelah mengetahui siswa juga menerapkannya di kehidupannya. Jadi, dengan adanya bahan ajar tematik terpadu dapat meningkatkan partisipasi siswa untuk melestarikan lingkungan. Adapun tujuan penelitian ini adalah menggunakan bahan ajar tematik terpadu untuk meningkatkan partisipasi peserta didik dalam pelestarian lingkungan.
\end{abstract}

Kata Kunci: Bahan Ajar, Tematik Terpadu, Partisipasi

\begin{abstract}
Abstrac
This research was conducted in Pasaman District Elementary School. This research is motivated because teachers are less able to involve students participating to participate in preserving the environment. Based on the analysis conducted by researchers, this is due to the material in the student book is still small, so the knowledge gained by students is still small, and the appearance of the student book is less attractive to students in learning.Efforts to get students to participate in preserving the environment can be linked to integrated learning. While the material on teacher books and student books provided at the Pasaman District Elementary School has been related to themes to facilitate teachers and students to carry out the teaching and learning process. However, the teacher's book and the student's book are still superficially material so it needs to be innovated especially the student book. To complete the student book, integrated thematic teaching materials are arranged that are useful for menhance learning objectives. One of the goals of learning is that students can apply what is learned in everyday life. For example, students already know ways to preserve the environment, after knowing students also apply it in their lives. So, with the existence of integrated thematic teaching materials can increase student participation to preserve the environment. The purpose of this study is to use integrated thematic teaching materials to improve students' participation in environmental conservation .
\end{abstract}

Keywords: Teaching Materials, Integrated Thematic, Participation

@ Jurnal Basicedu Prodi PGSD FIP UPTT 2019

$\triangle$ Corresponding author :

Address : Perumahan Tamiang Kec.Pasaman.Kab.Pasbar $\quad$ ISSN 2580-3735 (Media Cetak)

Email : trijunairawana50@gmail.com ISSN 2580-1147 (Media Online)

Phone : 081374928842 


\section{PENDAHULUAN}

Pendidikan keberhasilannya ditentukan oleh elemen yang berada dalam pendidikan tersebut terkhususnya guru. Potensi seorang peserta didik dapat dikembangkan secara maksimal oleh seorang guru dalam lembaga pendidikan. Melalui pendidikan kita juga dapat mengembangkan seluruh keterampilan dan potensi diri seorang peserta didik dalam menghadapi tantangan masa depannya. Pendidikan sangat berpengaruh bagi kemajuan sebuah bangsa. Dengan adanya pendidikan peserta didik dapat menjadi semakin bisa menghadapi tantangan kehidupan dengan cara yang sesuai dengan ajaran agama masing-masing peserta didik dan aturan yang berlaku dalam kehidupan. Pendidikan juga bisa meningkatkan keimanan peserta didik, dapat meningkatkan hubungan sosial, memperbaiki tingkah laku yang kurang baik ke arah yang lebih baik, meningkatkan kemandirian dan dapat memperbaiki maupun menghasilkan sebuah karya. Kemudian untuk merealisasikannya, guru juga harus berusaha meningkatkan mutu dan pengelolaan pendidikan dengan melakukan berbagai strategi dalam proses pembelajaran. Adapun beberapa strategi-strategi dalam pembelajaran misalnya guru terlebih dahulu harus mengetahui karakter peserta didik, kemudian mempersiapkan sumber belajar yang cocok dengan karakter peserta didik, menggunakan strategi pembelajaran yang sesuai, melaksanakan penilaian yang berkaitan dengan kognitif, afektif dan psikomotor, mennevaluasi pembelajaran, dan mengadakan perbaikan bagi siswa yang belum tuntas.

Berdasarkan pendapat tersebut maka tergambarlah dalam pelaksanaan pembelajaran, guru terlebih dahulu membuat perencanaan. Dalam perencanaan guru harus menetapkan prosedur, metode, teknik, evaluasi, KKM dan sebagainya. Dalam pelaksanaan pembelajaran guru hendaknya banyak menggunakan sumber belajar. Tetapi, kebanyakan guru di SD Kecamatan Pasaman hanya menggunakan buku- buku yang diterbitkan oleh lembaga yang berkepentingan di dalamnya. Bahan ajar atau sumber belajar yang digunakan dibagi menjadi beberapa tema. Di dalam buku tema yang digunakan terdapat tema yang membicarakan tentang melestarikan lingkunngan. Materi yang ada di dalam tema tersebut masih sangat sedikit untuk dapat mengembangtumbuhkan karakter partisipasi peserta didik dalam melaksanakan di kehidupan sehari-hari.

Berdasarkan permasalahan tentang sedikitnya materi tersebut, guru merasa kewalahan dalam mengembangkan karakter peserta didik dalam pembelajaran. Karakter peserta didik terhadap menjaga kelestarian lingkungan sangat rendah. Hal ini ditunjukan dari kebiasaan membuang sampah, buang air seni dan yang lainnya. Demikian juga dalam menjaga tumbuhtumbuhan yang ada disekitarnya yang sengaja ditanam oleh peserta didik atau oleh orang lain. Masih ada peserta didik sangat mudah untuk mencabut tanaman tersebut. Atau malas untuk menyiram tanaman yang telah diabagi dalam tugas piket. Masih-masih malas-malasan peserta didik melalaikan tugasnya. Berulangkali peserta didik diingatkan tentang hal tersebut dan berulang kali 
2084 Pengaruh bahan ajar tematik terpadu terhadap peningkatan partisipasi peserta didik melestarikan lingkungan di sekolah dasar - Tri Juna Irawana, Firman, Neviyarni

peserta didik melanggarnya

Adanya permasalahan yang ada di atas merasa perlu untuk mengembangkan bahan ajar yang dapat menjawab tantangan permasalahan yang di atas.Maka dalam penelitian pengembangan bahan ajar ini digunakan pendekatan terpadu. Hal ini dilandasi dengan diberlakukannya kurikulum 13 yang tidak lagi menegenal bidang studi tetapi muatan pembelajaran. Bahan ajar dikemas sedemikian rupa dengan menggunakan tema melestarikan lingkungan. Di dalam bahan ajar tematik terpadu ini disediakan materi materi yang berkesan bagi peserta didik. Misalnya adanya bacaan-bacaan yang berkaitan antara manusia dan linkungan, bacaan yang berisi perubahan lingkungan, materi usaha pelestarian lingkungan, dan dilengkapi gambar yang diberi warna yang menonjol sehingga. Di dalam bahan ajar tematik terpadu juga disediakan lembar kerja peserta didik yang membuat peserta didik semakin senang dan nyaman dalam kegiatan pembelajaran. Kemudian di dalam bahan ajar tersebut juga dimuat lagulagu yang berkaitan dengan tema. Dengan adanya bahan ajar tematik terpadu ini diharapkan pembelajaran yang akan dilaksanakan dalam kelas akan lebih menyenangkan dan membuat pelajaran tersebut lebih konstektual serta bermakna. Adapun pembelajaran dikatakan bermakna apabila pembelajaran tersebut dapat dipergunakan peserta didik dalam keseharian, tidak hanya sekedar mengetahui materi tetapi juga dapat menerapkannya di lingkungan sekolah, rumah dan masyarakat. Pembelajaran yang dilakukan di sekolah hendaknya jangan hanya sekedar pengetahuan yang hanya mengharapkan nilai ulangan harian, ujian tengah semester, ujian semester mendapat nilai yang tinggi. Karena kalau hanya mengharapkan nilai yang tinggi dari ujian-ujian tersebut maka pendidikan yang dilakukan di sekolah belum sepenuhnya berhasil. Karena yang lebih penting dari itu adalah peserta didik juga dapat mempergunakan ilmu yang didapatnya di sekolah untuk kelangsungan hidupnya yang sesuai dengan aturan dan norma-norma. Contohnya saja, seperti pembelajaran usaha melestarikan lingkungan, peserta didik tidak hanya dituntut mengetahui caracara pelestarian lingkungan, tetapi selain mengetahui peserta didik harus menerapkan pengetahuannya tentang usaha melestarikan lingkungan tersebut dalam kesehariannya, di manapun peserta didik tersebut tinggal. Untuk mencapai tujuan-tujuan yang diharapkan itu perlu dikembangkan berbagai bahan ajar yang menarik perhatian peserta didik. Bahan ajar tematik terpadu contohnya. Bahan ajar yang sesuai akan mempengaruhi ketercapaian dari pembelajaran. Guru jangan hanya menggunakan satu sumber belajar tetapi harus menggunakan banyak sumber belajar.

Sumber belajar bisa dikembangkan menjadi bahan ajar yang menarik bagi peserta didik. Peserta didik di sekolah dasar memiliki karakteristik yang berbeda dengan orang dewasa. Karakter peserta didik di sekolah dasar suka bermain sambil belajar. Jangan hanya mengharapkan hapalan saja terhadap peserta didik sekolah dasar, tetapi dibutuhkan juga pembelajaran-pembelajaran yang membuat peserta didik tertawa dan ceria. Sehingga peserta didik dalam pembelajaran tidak mersa terbebani dengan tugas-tugas yang diberikan guru, tetapi mereka merasa pembelajaran itu sesuatu yang harus diketahui dan perlu dipelajari dan dilakukan dalam keseharian. Dengan adanya bahan ajar tematik terpadu peserta didik semakin berpartisipasi dalam kegiatan pembelajaran. Kemudian, pembelajaran peserta didik di sekolah dasar hendaknya dikaitkan dengan dunia nyata, sehingga pembelajaran lebih 
bermakna. Kenyataannya di Indonesia, hal ini belum dilakukan guru. Pembelajaran di SD cenderung tidak kontekstual, bahan ajar yang digunakan kebanyakan hanya buku guru dan buku siswa. Pembelajaran tetap mengutamakan pengembangan aspek intelektual dengan buku teks pegangan guru menjadi sumber belajar utama.

Materi pelajaran yang disusun secara runtut yang digunakan dalam kegiatan pembelajaran dikenal dengan isitilah bahan ajar. Hal yang sama diungkapkan oleh Hamdani( 2011:120) Hal senada diungkapkan dalam Kemendiknas (2010:2) menjelaskan bahwa bahan ajar adalah segala bentuk bahan yang digunakan untuk membantu guru dalam melaksanakan proses pembelajaran. Kemudian Ahmad (2012:102) berpendapat bahan ajar adalah pengetahuan faktual, sarana dan prasarana yang dimanfaatkan guru sebelum dan sesudah pembelajaran. Model bahan ajar yang dapat digunakan atau dibuat dapat berupa printout nahkan yang dijilid menjadi modul, buku, video, atau yang lainnya.

Penunjang kegiatan belajar seperti yang tersebut di atas disesuaikan dengan cara pembelajaran yang akan kita pakai maupun pendekatan yang digunakan dalam kelas. Penggunaan alat penunjang tersebut dimaksudkan untuk membuat kegiatan belajar mengajar menjadi menyenangkan dan sesuai dengan fakta terjadi lapangan.

Pelaksanaan pembelajaran yang telah dilakukan selama ini di kelas V SD Kecamatan Pasaman belum menunjukan hasil yang maksimal. Perwujudan nilai-nilai yang dikembangkan di sekolah belum tampak dalam kehidupan sehari-hari peserta didik. Keterampilan untuk melaksanakan kewajibannya masih memprihatinkan. Misalnya kemampuan peserta didik dalam menjaga lingkungan masih jauh dari yang diharapkan, seperti masih banyak terlihat peserta didik yang membuang sampah di laci, membuang sampah di taman sekolah, Jurnal Basicedu Vol 3 No 4 November Tahun 2019 p-ISSN 2580-3735 e-ISSN 2580-1147 membiarkan rumput liar di sekitar taman,tidak menyiram bunga kalau tidak disuruh guru, jarang yang mau menanam bunga atau tanaman lain. Sementara dalam pembelajara sudah ada materi usaha pelestarian lingkungan, tetapi peserta didik belum bisa mengaplikasikannya dalam kehidupan sehari-hari.

Dari paparan yang telah diuraikan dapat disimpulkan masalah yang dihadapi adalah kurangnya materi pada buku sumber yang telah disediakan di buku yang dipakai peserta didik. Sehingga tujuan pembelajaran belum tercapai dengan baik. Jadi, disusunlah bahan ajar tematik terpadu yang menyenangkan bagi peserta didik untuk membacanya dan menambah pengetahuan peserta didik sehingga yang diharapkan ketercapaian tujuan pembelajaran tercapai khususnya berpartisipasi dalam melestarikan lingkungan.

\section{METODE}

Kegiatan yang dilakukan dalam memperbaiki permasalahan, peneliti menggunakan kegiatan penelitian pengembangan atau Research and development $(R \& D)$. Model pengemmbangan yang dipakai model $4 \mathrm{D}($ define, design, develop, dan disseminate). Dalam penelitian ini, produk yang dihasilkan adalah bahan ajar tematik terpadu.

Waktu dan tempat penelitian pengembangan ini dilaksanakan di beberapa SD di Kecamatan Pasaman, bulan Agustus-September 2019. Subjek Penelitian Subjek uji coba pada penelitian ini adalah peserta didik Sekolah Dasar di Kecamatan Pasaman. Adapun Prosedur penelitiannya adalah:

Tahap awal yang dilakukan pada penelitian pengembangan ini adalah melakukan kegiatan menganalisis tujuan kegiatan pembelajaran yang akan dilakukan diambil dari materi yang dikenal dengan istilah pendefinisian

(define) 
2086 Pengaruh bahan ajar tematik terpadu terhadap peningkatan partisipasi peserta didik melestarikan lingkungan di sekolah dasar - Tri Juna Irawana, Firman, Neviyarni

Langkah berikutnya adalah peneliti Teblai membuat rancangan dari bahan ajar yang akan dikembangkan meliputi : alat evaluasi, media dan lembar penilaian dikenal dengan istilah perancangan (design).

Selesai melakukan kegiatan merancang bahan ajar, peneliti mulai melakukan tahap pengembangan menghasilkan bahan ajar yang telah dirancang sebelumnya. Tahapan ini dikenal dengan istilah pengembangan (develop) setelah dilakukan penilaian kesesuain atau validitas dan revisi atau perbaikan.

Langkah yang dilakukan seterusnya adalah melakukan uji kebermanfaatan kepada siswa, yang selanjutnya akan diperbanyak sesuai dengan kebutuhan. Tahapan ini dikenal dengan istilah penyebaran ( disseminate)

Dalam pengujian keterpakaian dan keseuaian dalam penggunaan bahan ajar ini maka dikumpulkanlah informasi dalam bentuk angka atau data melalui lembar pertanyaan atau instrumen. Data yang akan dikumpulkan berupa informasi tentang keterpakaian atau efektivitas serta kepraktisan dalam pemakaiannya. Dalam penggumpulan informasi tersebut dikumpulkan dari informasi siswa sebagai pemakai bahan ajar melalui angket dan observasi. Demikian pula halnya dengan pendapat guru sebagai pemakai dari bahan ajar.

\section{Hasil dan Pembahasan}

Dari pelaksanaan kegiatan penelitian pengembangan yang dilakukan menggunakan bahan ajar yang dibuat terhadap partisipasi peserta didik dalam melestarikan lingkungan terpapar dalam tabel berikut ini:

\begin{tabular}{|c|c|c|}
\hline Unsur & skor & keterangan \\
\hline $\begin{array}{l}\text { Validasi } \\
\text { a. Bahan Ajar } \\
\text { b. RPP }\end{array}$ & $\begin{array}{l}3,75 \\
3,72\end{array}$ & $\begin{array}{l}\text { Sangat valid } \\
\text { Sangat valid }\end{array}$ \\
\hline $\begin{array}{l}\text { Praktikalitas } \\
\text { a. Observasi } \\
\text { Pelaksanaan } \\
\text { Pembelajaran } \\
\text { b. Angket } \\
\text { Praktikalitas } \\
\text { untuk Guru } \\
\text { c. Angket } \\
\text { Praktikalitas } \\
\text { untuk } \\
\text { peserta } \\
\text { didik }\end{array}$ & $\begin{array}{l}3,83 \\
3,85\end{array}$ & $\begin{array}{l}\text { Praktis } \\
\text { Praktis } \\
\text { Praktis }\end{array}$ \\
\hline $\begin{array}{l}\text { Efektivitas } \\
\text { (Tahap } \\
\text { Pengembangan) } \\
\text { Partisipasi } \\
\text { peserta } \\
\text { didik } \\
\text { a. Hasil Belajar } \\
\text { 1). afektif } \\
\text { 2). kognitif } \\
\text { 3).psikomotor }\end{array}$ & $\begin{array}{l}91,10 \\
88,20 \\
89,10\end{array}$ & $\begin{array}{l}\text { Sangat } \\
\text { Tinggi } \\
\\
\text { Sangat tinggi } \\
\text { Sangat tinggi } \\
\text { Sangat tinggi }\end{array}$ \\
\hline $\begin{array}{l}\text { Efektivitas } \\
\text { (Tahap } \\
\text { Penyebaran) } \\
\text { a. Partisipas } \\
\text { i peserta } \\
\text { didik } \\
\text { Hasil } \\
\text { Belajar : } \\
\text { 1). Afektif. } \\
\text { 2) kognitif } \\
\text { 3)psiskomo } \\
\text { tor }\end{array}$ & $\begin{array}{l}87,30 \\
88,40 \\
90,10\end{array}$ & $\begin{array}{l}\text { Sangat Baik } \\
\text { Sangat Baik } \\
\text { Sangat Baik }\end{array}$ \\
\hline
\end{tabular}

Tabel.Hasil Penelitian 
2087 Pengaruh bahan ajar tematik terpadu terhadap peningkatan partisipasi peserta didik melestarikan lingkungan di sekolah dasar - Tri Juna Irawana, Firman, Neviyarni

Pengembangan bahan ajar tematik terpadu berdasarkan hasil penelitian yang tampak pada tabel di atas untuk hasil validasi bahan ajar menunjukkan angka 3,75 yang berarti bahan ajar tersebut bisa dipakai. Demikian pula dengan hasil RPP 3,72 yang menunjukkan RPP sudah bisa dipakai dan diperbanyak.

Untuk tingkat praktikalitas untuk hasil observasi pelaksanaan pembelajaran menunjukkan hasil 3,81 yang praktis untuk dilaksanakan. Sedangkan hasil angket praktikalitas dari guru menunjukkan hasil 3,83 dari murid 3,85 menunjukkan guru dan siswa dapat menggunakannya secara praktis.

Pada efektivitas pada tahap pengembangan partisipasi dan hasil belajar menunjukkan hasil 91 ke atas yang menunjukkan hasil yang sangat tinggi, demikian pula dengan aspek yang lainnya menunjukkan hasil yang sangat baik karena menunjukkan hasil 80 ke atas.

Berdasarkan hal itu, dilakukanlah tahap penyebaran yang hasil efektivitasnya rata-rata menunjukkan angka 87 ke atas yang artinya sangat baik.Menurut Plomp (2007: 127) sebuah bahan ajar dikatakan praktis apabila bahan ajar tersebut dapat digunakan dengan mudah oleh guru dan siswa dalam pembelajaran. Untuk melihat apakah bahan ajar yang telah dikembangkan.

\section{Simpulan}

Berdasarkan hasil pembahasan yang disampaikan sebelumnya dapat dilihat perubahan pada peningkatan partisipasi siswa dalam melestarikan lingkungan melalui pengembangan bahan ajar. Bahan ajara yang dikembangkan dengan valid tersebut membuat siswa memahami konsep bagaimana cara melestarikan ligkungan sehingga membuat siswa menjadi mau ikut berpartisipasi dalam melestarikan lingkungan.

Bahan ajar yang telah valid tersebut digunakan dalam pembelajaran tematik di kelas V sekolah dasar. Bahan ajar tersebut membantu guru dan siswa dalam pelaksanaan pembelajaran.

Dari pembelajaran dengan menggunakan bahan ajar yang telah dikembangkan terlihat kemajuan dalam partisipasi siswa melestarikan lingkungan, dari tidak mau berpartisipasi menjadi mau ikut berpartisipasi.

Bahan ajar melalui proses validasi dan efektivitas terlebih dahulu.

Kemudian uji validasi bahan ajar dinyatakan valid dengan hasil validasi 3,75. Dengan hasil demikian maka bahan ajar sudah masuk dalam kategori valid dan dapat digunakan dalam meningkatkan partisipasi melestarikan lingkungan.

Sementara dari hasil praktikalitas bahan ajar yang telah di uji didapatkan hasil untuk hasil observasi, hasil angket praktikalitas untuk guru dan siswa serta hasil observasi bahan ajar diperoleh data dengan kesimpulan bahan ajar yang telah dikembangkan dalam kategori praktis untuk digunakan dalam meningkatkan partisipasi siswa melestarikan lingkungan.

Sedangkan hasil uji efektifitas yang dilakukan terhadap bahan ajar dengan mengambil data dari partisipasi dan hasil belajar siswa dari aspek dalam pembelajaran yaitu ditinjau dari afektif, kognitif dan psikomotor dapat disimpulkan bahan ajar yang telah dikembangkan terbukti dapat meningkatkan partisipasi dan hasil belajar siswa di lihat dari afektif, kognitif dan psikomotor.

Jadi kesimpulan akhir bahan ajar yang telah dikembangkan dapat meningkatkan partisipasi siswa dalam melestarikan lingkungan ditinjau dari hasil uji validasi, praktikalitas dan evektifitas dari bahan ajar. 
2088 Pengaruh bahan ajar tematik terpadu terhadap peningkatan partisipasi peserta didik melestarikan lingkungan di sekolah dasar - Tri Juna Irawana, Firman, Neviyarni

\section{Daftar Pustaka}

Putra ED, Marhamah M, dan Ramadan ZH. (2018). Pengembangan Bahan Ajar Tematik Berbasis Nilai-Nilai Budaya Melayu di Sekolah Dasar. Jurnal Aplikasi Iptek Indonesia.

Sariningsih, R.(2014). Pendekatan Kontektual untuk Meningkatkan Kemampuan Pemahaman Matematis Siswa SMP. Infinity

Journal,3(2),150.Https://doi.org/10.224 60/infinity.v3i2.60

Su'udiah F, Degeng INS dan Kuswandi, D.(2016).Pengembangan Buku Teks Tematik Berbasis Kontekstual. Jurnal Pendidikan: Teori Penelitian dan Pengembangan. 